Prepared in cooperation with the lowa Department of Transportation, the lowa Highway Research Board (lowa D0T Research Project TR-669), and the U.S. Army Corps of Engineers

\title{
Statistical Summaries of Selected lowa Streamflow Data Through September 2013
}

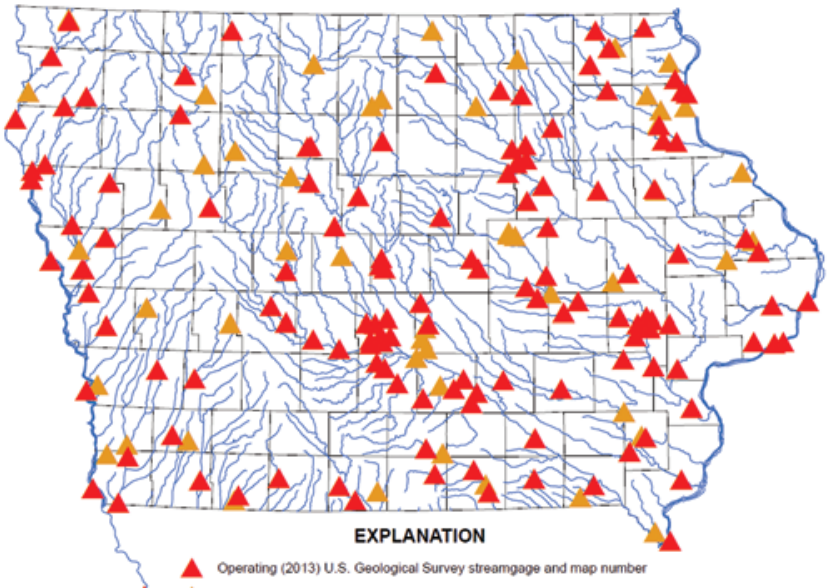

$\boldsymbol{\Delta} \Delta$

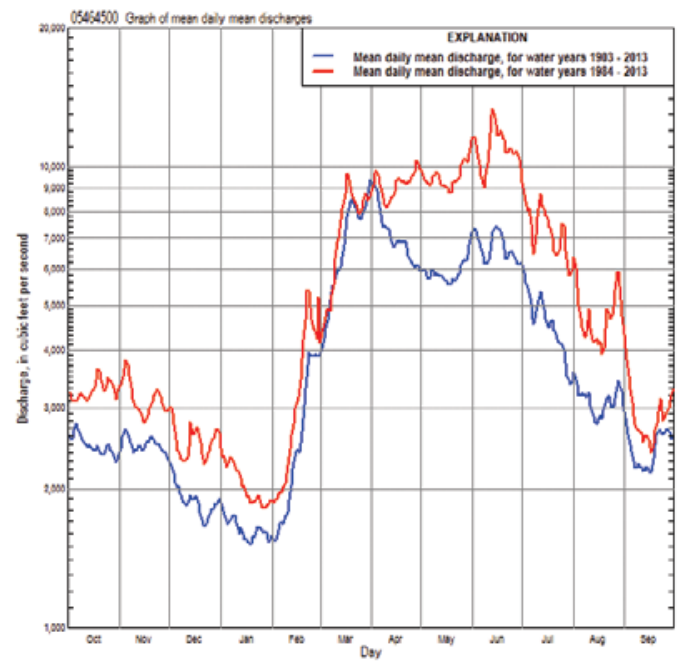

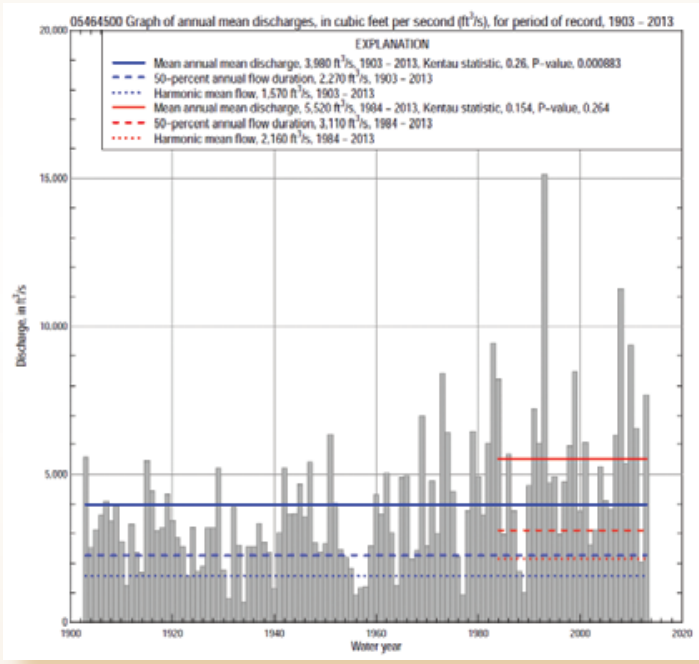

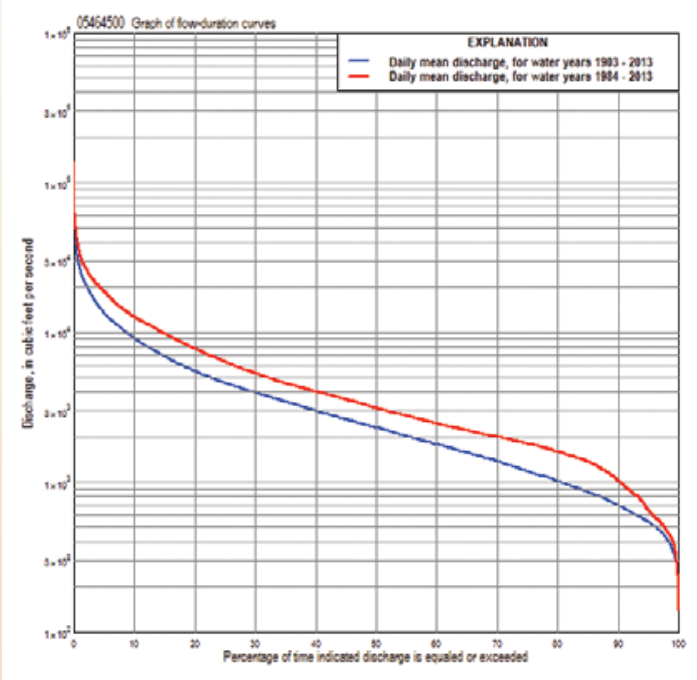

Open-File Report 2015-1214

U.S. Department of the Interior

U.S. Geological Survey 
Cover. Clockwise from upper left: Map of lowa streamgages, graph of annual mean discharges, graph of flow-duration curves, and graph of mean daily mean discharges. 


\section{Statistical Summaries of Selected lowa Streamflow Data Through September 2013}

By David A. Eash, Padraic S. O'Shea, Jared R. Weber, Kevin T. Nguyen, Nicholas L. Montgomery, and Adrian J. Simonson

Prepared in cooperation with the lowa Department of Transportation, the lowa Highway Research Board (lowa DOT Research Project TR-669), and the U.S. Army Corps of Engineers

Open-File Report 2015-1214 


\title{
U.S. Department of the Interior SALLY JEWELL, Secretary
}

\section{U.S. Geological Survey \\ Suzette M. Kimball, Acting Director}

\author{
U.S. Geological Survey, Reston, Virginia: 2015
}

For more information on the USGS - the Federal source for science about the Earth, its natural and living resources, natural hazards, and the environment—visit http://www.usgs.gov or call 1-888-ASK-USGS.

For an overview of USGS information products, including maps, imagery, and publications, visit http://www.usgs.gov/pubprod/.

Any use of trade, firm, or product names is for descriptive purposes only and does not imply endorsement by the U.S. Government.

Although this information product, for the most part, is in the public domain, it also may contain copyrighted materials as noted in the text. Permission to reproduce copyrighted items must be secured from the copyright owner.

Suggested citation:

Eash, D.A., O'Shea, P.S., Weber, J.R., Nguyen, K.T., Montgomery, N.L., and Simonson, A.J., 2015, Statistical summaries of selected lowa streamflow data through September 2013: U.S. Geological Survey Open-File Report 2015-1214, 18 p., http://dx.doi.org/10.3133/ofr20151214.

ISSN 2331-1258 (online) 


\section{Acknowledgments}

The authors gratefully acknowledge Shirley Johnson, Chance Bitner, Joshua Mellinger, and Ann Banitt (U.S. Army Corps of Engineers) for their assistance in providing estimates of, and the presentation of, flood-frequency discharges for regulated streamgages in lowa.

The authors also express gratitude to the following U.S. Geological Survey (USGS) personnel: David Lorenz, for his assistance in providing sections of the R-script code used to create the graphs in this report; Ed Fischer, for his work to develop computer scripts to calculate flowduration values for each water year of streamflow record and to retrieve streamgage descriptions for all streamgages included in this study; Kris Lund, for her work to modify Ed Fischer's scripts and to develop additional scripts to meet specific requirements for this study; and to the many U.S. Geological Survey employees who assisted with the collection and analysis of streamflow data used in this report. Flood data used in this report often were collected during adverse conditions, and the efforts of these individuals made this report possible. 



\section{Contents}

Acknowledgments ……...................................................................................................................

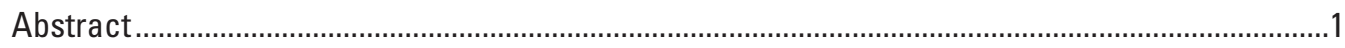

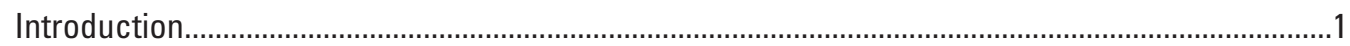

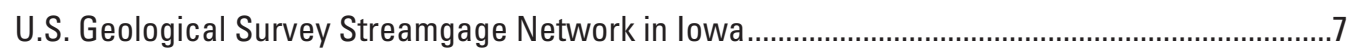

Explanation of Streamgage Summaries and Streamflow Statistics ...............................................10

Streamgage Description.................................................................................................

Graph of Annual Mean Discharges ....................................................................................12

Graph of Mean Daily Mean Discharges .............................................................................12

Graph of Flow-Duration Curves ..........................................................................................12

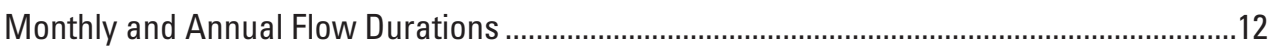

Annual Exceedance Probability of Instantaneous Peak Discharges ......................................12

Annual Exceedance Probability of High Discharges and Annual

Nonexceedance Probability of Low Discharges .........................................................13

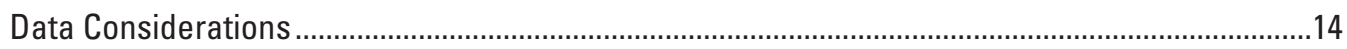

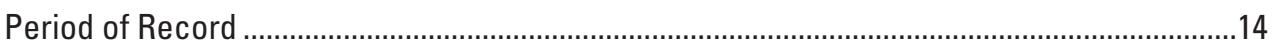

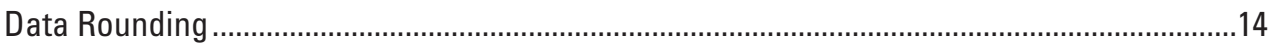

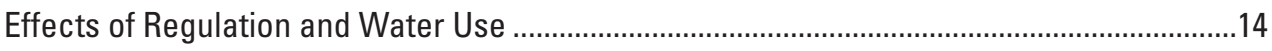

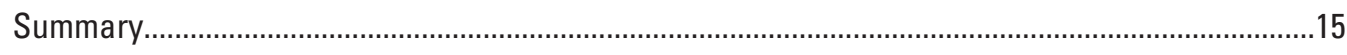

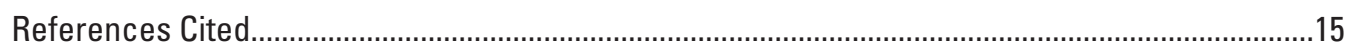

\section{Figures}

1. Map showing location of U.S. Geological Survey streamgages for which statistical summaries are calculated in this report...........................................................................

2. Graph showing number of daily-discharge streamgages operated in lowa each

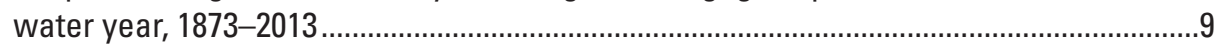

\section{Tables}

1. Streamgages in lowa included in this study .................................................................

2. Significant figures used for reporting flow duration and probability discharges............14 


\section{Conversion Factors}

[Inch/Pound to International System of Units]

\begin{tabular}{|c|c|c|}
\hline Multiply & By & To obtain \\
\hline \multicolumn{3}{|c|}{ Length } \\
\hline foot $(\mathrm{ft})$ & 0.3048 & meter $(\mathrm{m})$ \\
\hline mile (mi) & 1.609 & kilometer (km) \\
\hline \multicolumn{3}{|c|}{ Area } \\
\hline square mile $\left(\mathrm{mi}^{2}\right)$ & 2.590 & square kilometer $\left(\mathrm{km}^{2}\right)$ \\
\hline \multicolumn{3}{|c|}{ Flow rate } \\
\hline cubic foot per second $\left(\mathrm{ft}^{3} / \mathrm{s}\right)$ & 0.02832 & cubic meter per second $\left(\mathrm{m}^{3} / \mathrm{s}\right)$ \\
\hline
\end{tabular}

\section{Datums}

Elevation or vertical coordinate information is referenced to the National Geodetic Vertical Datum of 1929 (NGVD 29) or mean sea level. The NGVD 29 can be converted to the North American Vertical Datum of 1988 by using the National Geodetic Survey conversion utility (U.S. Department of Commerce, National Oceanic and Atmospheric Administration, and National Climatic Data Center, 2013).

Horizontal coordinate information is referenced to the North American Datum of 1983 (NAD 83) or North American Datum of 1927 (NAD 27).

\section{Supplemental Information}

A water year is the 12-month period from 0ctober 1 through September 30. The water year is designated by the calendar year in which the water year ends and includes 9 of the 12 months of that year. Thus, the water year ending September 30, 2013, is the "2013 water year."

A climatic year is the 12-month period from April 1 through March 31. The climatic year is designated by the calendar year in which the climatic year ends and includes 3 of the 12 months of that year. Thus, the climatic year ending March 31, 2013, is the "2013 climatic year."

\section{Abbreviations}

AEP

ANNIE

ANP

BASINS

DVstats

EMA

EPA annual exceedance probability

U.S. Geological Survey interactive hydrologic analyses and data management computer program

annual nonexceedance probability

Better Assessment Science Integrating Point and Nonpoint Sources

U.S. Geological Survey R-package functions to manipulate daily-values data

expected moments algorithm AEP analysis

U.S. Environmental Protection Agency 
IA

Kentau statistic

lat

long

MGB

$N$-day

NE

NOAA

NRCS

NW

NWISWeb

$P$-value

PeakF0

R

RI

RRE

SE

sec.

SW

smwrBase

smwrGraphs

smwrStats

SWSTAT

$\mathrm{T}$

USGS

USGS SW Toolbox

WaterWatch

WIE lowa

Kendall's tau statistic, a measure of the correlation between the streamflow data series (discharges) and time (water years or climatic years)

latitude

longitude

multiple Grubbs-Beck low-outlier test

number of consecutive days

northeast

National Oceanic and Atmospheric Administration

Natural Resources Conservation Service

northwest

National Water Information System Web interface

represents a 95-percent confidence-level probability that a true null hypothesis of no trend is erroneously rejected, $P$-values less than or equal to 5 percent $(\alpha=0.05)$ indicate statistically significant trends (positive or negative)

U.S. Geological Survey computer program that implements both

Bulletin 17B and EMA procedures for flood-frequency analysis

range

recurrence interval

regional regression equation

southeast

section

southwest

U.S. Geological Survey R-package functions to import and manipulate hydrologic data

U.S. Geological Survey R-package graphing functions

U.S. Geological Survey R-package general tools for hydrologic data and trend analysis

U.S. Geological Survey Surface-Water Statistics computer program

township

U.S. Geological Survey

U.S. Geological Survey surface-water analysis program that includes the U.S. Geological Survey Surface-Water Statistics (SWSTAT) computer program

A U.S. Geological Survey Web site that displays maps, graphs, and tables describing real-time, recent, and past streamflow conditions for streamgages in the United States.

Weighted Independent Estimates 



\title{
Statistical Summaries of Selected lowa Streamflow Data Through September 2013
}

\author{
By David A. Eash, Padraic S. O'Shea, Jared R. Weber, Kevin T. Nguyen, Nicholas L. Montgomery, and \\ Adrian J. Simonson
}

\section{Abstract}

Statistical summaries of streamflow data collected at 184 streamgages in Iowa are presented in this report. All streamgages included for analysis have at least 10 years of continuous record collected before or through September 2013. This report is an update to two previously published reports that presented statistical summaries of selected Iowa streamflow data through September 1988 and September 1996. The statistical summaries include (1) monthly and annual flow durations, (2) annual exceedance probabilities of instantaneous peak discharges (flood frequencies), (3) annual exceedance probabilities of high discharges, and (4) annual nonexceedance probabilities of low discharges and seasonal low discharges. Also presented for each streamgage are graphs of the annual mean discharges, mean annual mean discharges, 50-percent annual flow-duration discharges (median flows), harmonic mean flows, mean daily mean discharges, and flow-duration curves. Two sets of statistical summaries are presented for each streamgage, which include (1) long-term statistics for the entire period of streamflow record and (2) recent-term statistics for or during the 30-year period of record from 1984 to 2013. The recent-term statistics are only calculated for streamgages with streamflow records pre-dating the 1984 water year and with at least 10 years of record during 1984-2013. The streamflow statistics in this report are not adjusted for the effects of water use; although some of this water is used consumptively, most of it is returned to the streams.

\section{Introduction}

Information concerning streamflow characteristics is essential for the development and management of surfacewater resources. Statistical analyses of streamflow data provide information about the spatial and temporal characteristics of streamflow. Project designers, water- and land-use managers, and hydrologists need information on all aspects of streamflow to evaluate various hydraulic and hydrologic designs or land-use alternatives. To address this need, the
U.S. Geological Survey (USGS), in cooperation with the Iowa Department of Transportation, the Iowa Highway Research Board (Iowa DOT Research Project TR-669), and the U.S. Army Corps of Engineers, prepared statistical summaries based on streamflow data available through September 2013 for operating and discontinued streamgages in and near Iowa.

This report presents statistical summaries of streamflow data for 184 streamgages that have at least 10 years of continuous record collected before or through September 2013. A link to the statistical summaries calculated for each streamgage is listed in table 1. The streamgages are located in Iowa except for three Missouri River streamgages that are located in Nebraska. The previous Iowa streamflow statistics reports presented summaries for 144 streamgages that had data collected before or through September 1988 (Fischer and others, 1990) and summaries for 156 streamgages that had data collected before or through September 1996 (Fischer and Eash, 1998); thus, the present report reflects the addition of 28 streamgages and the collection of 17 more years of record at operating streamgages.

The statistical summaries presented for each streamgage are (1) monthly and annual flow durations; (2) annual exceedance probabilities (AEP) of instantaneous peak discharges (flood frequencies); (3) AEPs of high discharges; and (4) annual nonexceedance probabilities (ANP) of low discharges and seasonal low discharges. Also presented for each streamgage is a description of the streamgage; links to all available data for the streamgage through the USGS National Water Information System Web interface (NWISWeb) (U.S. Geological Survey, 2015a) and through the USGS WaterWatch Toolkit (U.S. Geological Survey, 2015b); and graphs of the annual mean discharges, mean annual mean discharges, 50-percent annual flow-duration discharges (median flows), harmonic mean flows, mean daily mean discharges, and flow-duration curves. WaterWatch is a Web site that displays maps, graphs, and tables describing realtime, recent, and past streamflow conditions for streamgages in the United States; the real-time information generally is updated on an hourly basis. Two sets of statistical summaries are presented for each streamgage, which include (1) longterm statistics for the entire period of streamflow record and (2) recent-term statistics for or during the 30-year period of 
record from 1984 to 2013. The recent-term statistics are only calculated for streamgages with streamflow records pre-dating the 1984 water year and with at least 10 years of record during 1984-2013. A water year is the 12-month period from October 1 through September 30. The water year is designated by the calendar year in which the water year ends and includes 9 of the 12 months of that year. Thus, the water year ending September 30, 2013, is the "2013 water year." A 30-year period of record (1984-2013) was selected for the recent-term statistics because this record length is used by the National Oceanic and Atmospheric Administration (NOAA), the World
Meteorological Organization, and the Natural Resources Conservation Service (NRCS) for calculating 30-year climatic and hydrologic normals (U.S. Department of Commerce, National Oceanic and Atmospheric Administration, 2015; World Meteorological Organization, 2015; Natural Resources Conservation Service, 2015), and this record length is essential for assessing trends (U.S. Geological Survey, 2005; Dixon and others, 2006).

Users of this report are responsible for assessing the suitability and applicability of the statistics for their requirements.

Table 1. Streamgages in lowa included in this study. Streamflow statistics for the streamgages are available at http://dx.doi.org/10.3133/ofr20151214.

[no., number]

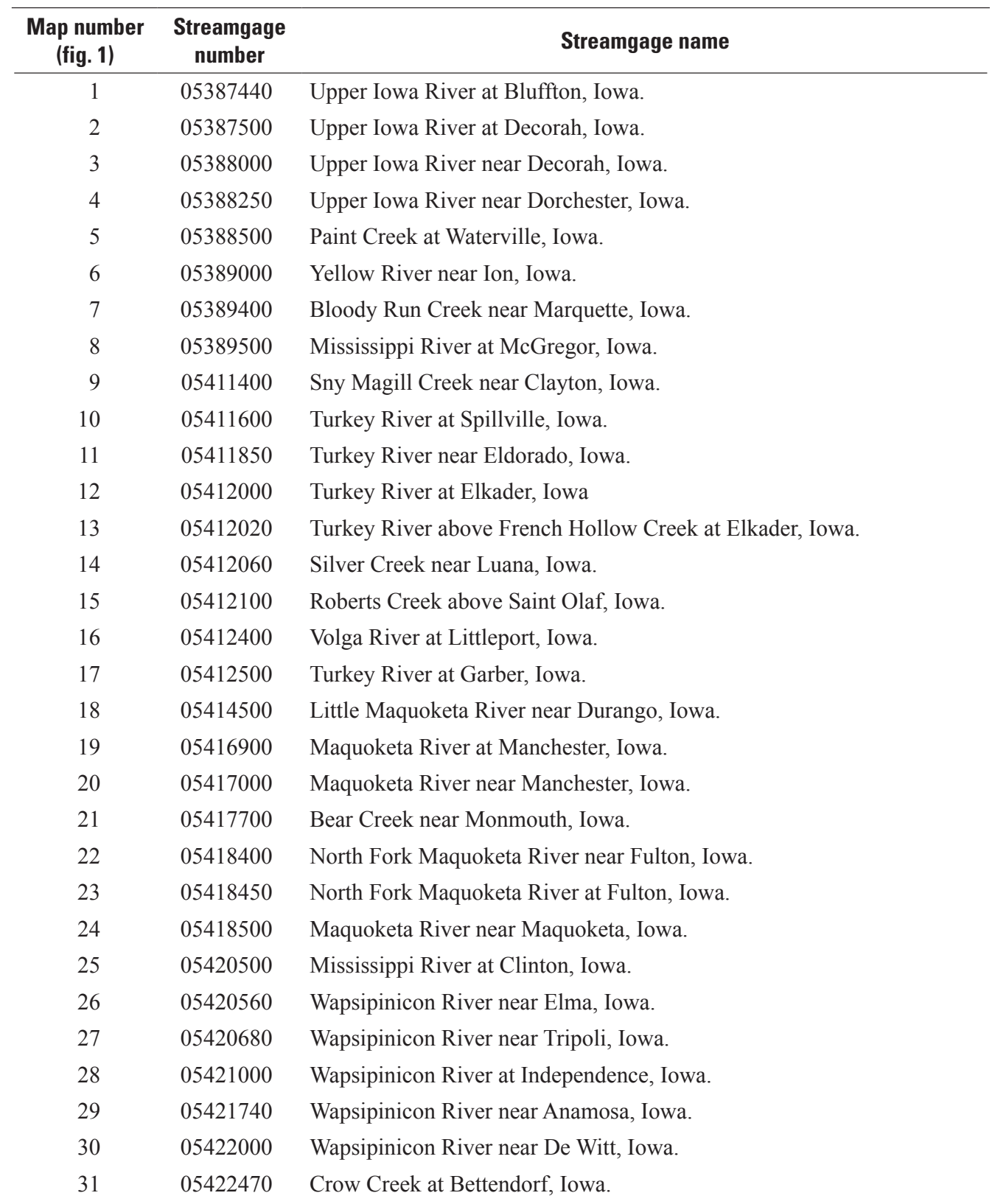


Table 1. Streamgages in lowa included in this study.-Continued. Streamflow statistics for the streamgages are available at http://dx.doi.org/10.3133/ofr20151214.

[no., number]

\begin{tabular}{|c|c|c|}
\hline $\begin{array}{l}\text { Map number } \\
\text { (fig. 1) }\end{array}$ & $\begin{array}{c}\text { Streamgage } \\
\text { number }\end{array}$ & Streamgage name \\
\hline 32 & 05422560 & Duck Creek at 110th Avenue at Davenport, Iowa. \\
\hline 33 & 05422600 & Duck Creek at Duck Creek Golf Course at Davenport, Iowa. \\
\hline 34 & 05448500 & West Branch Iowa River near Klemme, Iowa. \\
\hline 35 & 05449000 & East Branch Iowa River near Klemme, Iowa. \\
\hline 36 & 05449500 & Iowa River near Rowan, Iowa. \\
\hline 37 & 05451210 & South Fork Iowa River northeast of New Providence, Iowa. \\
\hline 38 & 05451500 & Iowa River at Marshalltown, Iowa. \\
\hline 39 & 05451700 & Timber Creek near Marshalltown, Iowa. \\
\hline 40 & 05451900 & Richland Creek near Haven, Iowa. \\
\hline 41 & 05452000 & Salt Creek near Elberon, Iowa. \\
\hline 42 & 05452200 & Walnut Creek near Hartwick, Iowa. \\
\hline 43 & 05452500 & Iowa River near Belle Plaine, Iowa. \\
\hline 44 & 05453000 & Big Bear Creek at Ladora, Iowa. \\
\hline 45 & 05453100 & Iowa River at Marengo, Iowa. \\
\hline 46 & 05453520 & Iowa River below Coralville Dam near Coralville, Iowa. \\
\hline 47 & 05454000 & Rapid Creek near Iowa City, Iowa. \\
\hline 48 & 05454220 & Clear Creek near Oxford, Iowa. \\
\hline 49 & 05454300 & Clear Creek near Coralville, Iowa. \\
\hline 50 & 05454500 & Iowa River at Iowa City, Iowa. \\
\hline 51 & 05455000 & Ralston Creek at Iowa City, Iowa. \\
\hline 52 & 05455010 & South Branch Ralston Creek at Iowa City, Iowa. \\
\hline 53 & 05455100 & Old Mans Creek near Iowa City, Iowa. \\
\hline 54 & 05455500 & English River at Kalona, Iowa. \\
\hline 55 & 05455700 & Iowa River near Lone Tree, Iowa. \\
\hline 56 & 05457700 & Cedar River at Charles City, Iowa. \\
\hline 57 & 05458000 & Little Cedar River near Ionia, Iowa. \\
\hline 58 & 05458300 & Cedar River at Waverly, Iowa. \\
\hline 59 & 05458500 & Cedar River at Janesville, Iowa. \\
\hline 60 & 05458900 & West Fork Cedar River at Finchford, Iowa. \\
\hline 61 & 05459000 & Shell Rock River near Northwood, Iowa. \\
\hline 62 & 05459500 & Winnebago River at Mason City, Iowa. \\
\hline 63 & 05460500 & Shell Rock River at Marble Rock, Iowa. \\
\hline 64 & 05462000 & Shell Rock River at Shell Rock, Iowa. \\
\hline 65 & 05463000 & Beaver Creek at New Hartford, Iowa. \\
\hline 66 & 05463500 & Black Hawk Creek at Hudson, Iowa. \\
\hline 67 & 05464000 & Cedar River at Waterloo, Iowa. \\
\hline 68 & 05464130 & Fourmile Creek near Lincoln, Iowa. \\
\hline 69 & 05464133 & Halfmile Creek near Gladbrook, Iowa. \\
\hline 70 & 05464137 & Fourmile Creek near Traer, Iowa. \\
\hline 71 & 05464220 & Wolf Creek near Dysart, Iowa. \\
\hline 72 & 05464500 & Cedar River at Cedar Rapids, Iowa. \\
\hline
\end{tabular}


Table 1. Streamgages in lowa included in this study.-Continued. Streamflow statistics for the streamgages are available at http://dx.doi.org/10.3133/ofr20151214.

[no., number]

\begin{tabular}{|c|c|c|}
\hline $\begin{array}{l}\text { Map number } \\
\text { (fig. 1) }\end{array}$ & $\begin{array}{c}\text { Streamgage } \\
\text { number }\end{array}$ & Streamgage name \\
\hline 73 & 05464640 & Prairie Creek at Fairfax, Iowa. \\
\hline 74 & 05464942 & Hoover Creek at Hoover National Historic Site at West Branch, Iowa. \\
\hline 75 & 05465000 & Cedar River near Conesville, Iowa. \\
\hline 76 & 05465500 & Iowa River at Wapello, Iowa. \\
\hline 77 & 05470000 & South Skunk River near Ames, Iowa. \\
\hline 78 & 05470500 & Squaw Creek at Ames, Iowa. \\
\hline 79 & 05471000 & South Skunk River below Squaw Creek near Ames, Iowa. \\
\hline 80 & 05471040 & Squaw Creek near Colfax, Iowa. \\
\hline 81 & 05471050 & South Skunk River at Colfax, Iowa. \\
\hline 82 & 05471200 & Indian Creek near Mingo, Iowa. \\
\hline 83 & 05471500 & South Skunk River near Oskaloosa, Iowa. \\
\hline 84 & 05472500 & North Skunk River near Sigourney, Iowa. \\
\hline 85 & 05473000 & Skunk River at Coppock, Iowa. \\
\hline 86 & 05473400 & Cedar Creek near Oakland Mills, Iowa. \\
\hline 87 & 05473450 & Big Creek North of Mount Pleasant, Iowa. \\
\hline 88 & 05473500 & Big Creek near Mount Pleasant, Iowa. \\
\hline 89 & 05474000 & Skunk River at Augusta, Iowa. \\
\hline 90 & 05474500 & Mississippi River at Keokuk, Iowa. \\
\hline 91 & 05476500 & Des Moines River at Estherville, Iowa. \\
\hline 92 & 05476750 & Des Moines River at Humboldt, Iowa. \\
\hline 93 & 05478000 & East Fork Des Moines River near Burt, Iowa. \\
\hline 94 & 05479000 & East Fork Des Moines River at Dakota City, Iowa. \\
\hline 95 & 05480000 & Lizard Creek near Clare, Iowa. \\
\hline 96 & 05480500 & Des Moines River at Fort Dodge, Iowa. \\
\hline 97 & 05481000 & Boone River near Webster City, Iowa. \\
\hline 98 & 05481300 & Des Moines River near Stratford, Iowa. \\
\hline 99 & 05481500 & Des Moines River near Boone, Iowa. \\
\hline 100 & 05481650 & Des Moines River near Saylorville, Iowa. \\
\hline 101 & 05481950 & Beaver Creek near Grimes, Iowa. \\
\hline 102 & 05482000 & Des Moines River at 2nd Avenue at Des Moines, Iowa. \\
\hline 103 & 05482135 & North Raccoon River near Newell, Iowa. \\
\hline 104 & 05482170 & Big Cedar Creek near Varina, Iowa. \\
\hline 105 & 05482300 & North Raccoon River near Sac City, Iowa. \\
\hline 106 & 05482500 & North Raccoon River near Jefferson, Iowa. \\
\hline 107 & 05483000 & East Fork Hardin Creek near Churdan, Iowa. \\
\hline 108 & 05483450 & Middle Raccoon River near Bayard, Iowa. \\
\hline 109 & 05483600 & Middle Raccoon River at Panora, Iowa. \\
\hline 110 & 05484000 & South Raccoon River at Redfield, Iowa. \\
\hline 111 & 05484500 & Raccoon River at Van Meter, Iowa. \\
\hline 112 & 05484650 & Raccoon River at 63rd Street at Des Moines, Iowa. \\
\hline 113 & 05484800 & Walnut Creek at Des Moines, Iowa. \\
\hline
\end{tabular}


Table 1. Streamgages in lowa included in this study.-Continued. Streamflow statistics for the streamgages are available at http://dx.doi.org/10.3133/ofr20151214.

[no., number]

\begin{tabular}{|c|c|c|}
\hline $\begin{array}{l}\text { Map number } \\
\text { (fig. 1) }\end{array}$ & $\begin{array}{c}\text { Streamgage } \\
\text { number }\end{array}$ & Streamgage name \\
\hline 114 & 05484900 & Raccoon River at Fleur Drive at Des Moines, Iowa. \\
\hline 115 & 05485500 & Des Moines River below Raccoon River at Des Moines, Iowa. \\
\hline 116 & 05485605 & Fourmile Creek near Ankeny, Iowa. \\
\hline 117 & 05485640 & Fourmile Creek at Des Moines, Iowa. \\
\hline 118 & 05486000 & North River near Norwalk, Iowa. \\
\hline 119 & 05486490 & Middle River near Indianola, Iowa. \\
\hline 120 & 05487470 & South River near Ackworth, Iowa. \\
\hline 121 & 05487500 & Des Moines River near Runnells, Iowa. \\
\hline 122 & 05487540 & Walnut Creek near Prairie City, Iowa. \\
\hline 123 & 05487550 & Walnut Creek near Vandalia, Iowa. \\
\hline 124 & 05487980 & White Breast Creek near Dallas, Iowa. \\
\hline 125 & 05488000 & White Breast Creek near Knoxville, Iowa. \\
\hline 126 & 05488110 & Des Moines River near Pella, Iowa. \\
\hline 127 & 05488200 & English Creek near Knoxville, Iowa. \\
\hline 128 & 05488500 & Des Moines River near Tracy, Iowa. \\
\hline 129 & 05489000 & Cedar Creek near Bussey, Iowa. \\
\hline 130 & 05489500 & Des Moines River at Ottumwa, Iowa. \\
\hline 131 & 05490500 & Des Moines River at Keosauqua, Iowa. \\
\hline 132 & 05491000 & Sugar Creek near Keokuk, Iowa. \\
\hline 133 & 05494300 & Fox River at Bloomfield, Iowa. \\
\hline 134 & 05494500 & Fox River at Cantril, Iowa. \\
\hline 135 & 06483270 & Rock River at Rock Rapids, Iowa. \\
\hline 136 & 06483290 & Rock River below Tom Creek at Rock Rapids, Iowa. \\
\hline 137 & 06483500 & Rock River near Rock Valley, Iowa. \\
\hline 138 & 06484000 & Dry Creek at Hawarden, Iowa. \\
\hline 139 & 06485500 & Big Sioux River at Akron, Iowa. \\
\hline 140 & 06486000 & Missouri River at Sioux City, Iowa. \\
\hline 141 & 06600000 & Perry Creek at 38th Street at Sioux City, Iowa. \\
\hline 142 & 06600100 & Floyd River at Alton, Iowa. \\
\hline 143 & 06600300 & West Branch Floyd River near Struble, Iowa. \\
\hline 144 & 06600500 & Floyd River at James, Iowa. \\
\hline 145 & 06601200 & Missouri River at Decatur, Iowa. \\
\hline 146 & 06602020 & West Fork Ditch at Hornick, Iowa. \\
\hline 147 & 06602400 & Monona-Harrison Ditch near Turin, Iowa. \\
\hline 148 & 06605000 & Ocheyedan River near Spencer, Iowa. \\
\hline 149 & 06605600 & Little Sioux River at Gillett Grove, Iowa. \\
\hline 150 & 06605850 & Little Sioux River at Linn Grove, Iowa. \\
\hline 151 & 06606600 & Little Sioux River at Correctionville, Iowa. \\
\hline 152 & 06606700 & Little Sioux River near Kennebec, Iowa. \\
\hline 153 & 06607000 & Odebolt Creek near Arthur, Iowa. \\
\hline 154 & 06607200 & Maple River at Mapleton, Iowa. \\
\hline
\end{tabular}


Table 1. Streamgages in lowa included in this study.-Continued. Streamflow statistics for the streamgages are available at http://dx.doi.org/10.3133/ofr20151214.

[no., number]

\begin{tabular}{ccl}
\hline $\begin{array}{c}\text { Map number } \\
\text { (fig. 1) }\end{array}$ & $\begin{array}{c}\text { Streamgage } \\
\text { number }\end{array}$ & \multicolumn{1}{c}{ Streamgage name } \\
\hline 155 & 06607500 & Little Sioux River near Turin, Iowa. \\
156 & 06608500 & Soldier River at Pisgah, Iowa. \\
157 & 06609500 & Boyer River at Logan, Iowa. \\
158 & 06610000 & Missouri River at Omaha, Nebraska. \\
159 & 06610500 & Indian Creek at Council Bluffs, Iowa. \\
160 & 06610520 & Mosquito Creek near Earling, Iowa. \\
161 & 06806000 & Waubonsie Creek near Bartlett, Iowa. \\
162 & 06807000 & Missouri River at Nebraska City, Nebraska. \\
163 & 06807410 & West Nishnabotna River at Hancock, Iowa. \\
164 & 06808000 & Mule Creek near Malvern, Iowa. \\
165 & 06808500 & West Nishnabotna River at Randolph, Iowa. \\
166 & 06809000 & Davids Creek near Hamlin, Iowa. \\
167 & 06809210 & East Nishnabotna River near Atlantic, Iowa. \\
168 & 06809500 & East Nishnabotna River at Red Oak, Iowa. \\
169 & 06810000 & Nishnabotna River above Hamburg, Iowa. \\
170 & 06811840 & Tarkio River at Stanton, Iowa. \\
171 & 06813500 & Missouri River at Rulo, Nebraska \\
172 & 06817000 & Nodaway River at Clarinda, Iowa. \\
173 & 06818750 & Platte River near Diagonal, Iowa. \\
174 & 06819185 & East Fork One Hundred and Two River at Bedford, Iowa. \\
175 & 06819190 & East Fork One Hundred and Two River near Bedford, Iowa. \\
176 & 06897950 & Elk Creek near Decatur City, Iowa. \\
177 & 06898000 & Thompson River at Davis City, Iowa. \\
178 & 06898400 & Weldon River near Leon, Iowa. \\
179 & 06903400 & Chariton River near Chariton, Iowa. \\
180 & 06903500 & Honey Creek near Russell, Iowa. \\
181 & 06903700 & South Fork Chariton River near Promise City, Iowa. \\
182 & 06903900 & Chariton River near Rathbun, Iowa. \\
183 & 06904000 & Chariton River near Centerville, Iowa. \\
184 & 06904010 & Chariton River near Moulton, Iowa. \\
\hline & & \\
\hline
\end{tabular}




\section{U.S. Geological Survey Streamgage Network in lowa}

The USGS is the primary Federal agency responsible for the collection of the Nation's streamflow data. In 2013, the USGS streamgage network consisted of nearly 8,000 streamgages nationwide, most collecting real-time data (Jian and others, 2014). In Iowa, the network consisted of 153 continuous-record or daily-discharge streamgages in 2013 (Rantz and others, 1982); all were real-time streamgages except for one. Real-time data are recorded at 15-minute intervals, stored onsite, and then transmitted to USGS offices every hour. Recording and transmission times may be more frequent during critical events. Data from real-time sites are relayed to USGS offices by way of satellite, telephone, and (or) radio and are available for viewing within minutes of arrival; data for Iowa are available at http://waterdata.usgs.gov/ia/nwis/ current/?type=flow.

The first systematic collection of streamflow data in Iowa was made in 1873 when the USGS began collecting data at Mississippi River at Clinton (streamgage 05420500, fig. 1, map number 25; formerly published as Mississippi River at Le Claire, Iowa, until 1939). Additional streamgages were installed in 1878 at Mississippi River at Keokuk (streamgage 05474500, fig. 1, map number 90) and in 1897 at Missouri River at Sioux City (streamgage 06486000, fig. 1, map number 140; monthly discharges only until 1928 when daily discharges became available). The streamgages at Clinton, Keokuk, and Sioux City are still in operation in the Iowa streamgage network.

The USGS established five streamgages on interior streams in Iowa between 1903 and 1905, some of which were discontinued after a short period of operation. Dailydischarge records are continuous since 1903 for Iowa River at Iowa City (streamgage 05454500, fig. 1, map number 50) and Cedar River at Cedar Rapids (streamgage 05464500, fig. 1, map number 72) (Burmeister, 1970). Since that time, the Iowa USGS streamgage network has grown to include over 150 streamgages in operation around the State. A chart of the number of Iowa streamgages operated each water year since the first streamgage was installed is shown in figure 2; note that the number of streamgages shown in figure 2 does not exactly correlate with previously published numbers (Fischer and Eash, 1998; Fischer and others, 1990).

The Federal-State cooperative program for the collection of streamflow records in Iowa was established in 1914. The streamgage network increased from 14 streamgages in 1914 to 28 streamgages in 1922 . The cooperative program was dissolved in 1928 and the number of streamgages decreased to 17. The cooperative program was resumed in 1932 (Burmeister, 1970), and by 1935 the number of streamgages increased to 37 .

By 1940, the number of streamgages increased to 63 , primarily because of the U.S. Army Corps of Engineer's flood-control program during the late 1930s (Burmeister, 1970). Since 1940, the streamgage network increased steadily from 61 streamgages in 1945 to 126 streamgages in 1968. The size of the network has fluctuated annually since 1968 from a minimum of 111 streamgages in 1984 to a maximum of 153 streamgages in 2013.

The streamgage network is not a network in the purest sense. Data collected at one streamgage or group of streamgages may be intended to answer different questions than data collected at other streamgages. Rather, the network is a mixture of many individual networks with different purposes and sources of funding. Fortunately, many USGS streamgages provide data that are useful for purposes other than that for which the streamgage was originally installed (Wahl and Crippen, 1984). In 1995, the USGS conducted a survey of users of the USGS streamgage network in Iowa to determine more definitively who uses streamflow data and for what purposes the data are used. The survey responses indicated that streamflow data collected at many streamgages in Iowa often are used by other agencies for purposes other than originally planned (Fischer, 1996). Additional information on the importance of streamgages and the use of streamflow information is provided at http://water.usgs.gov/nsip/uses9. html. 


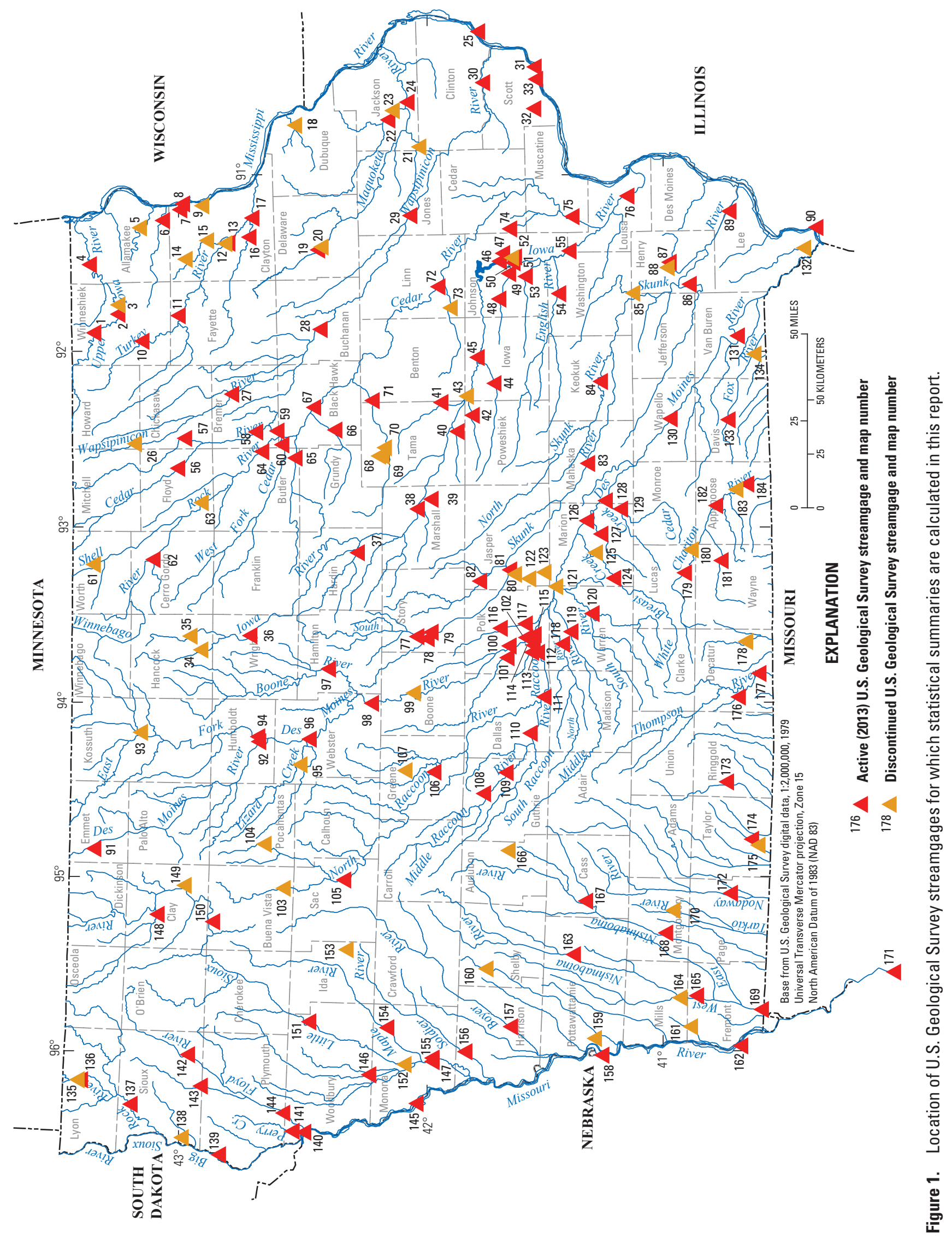




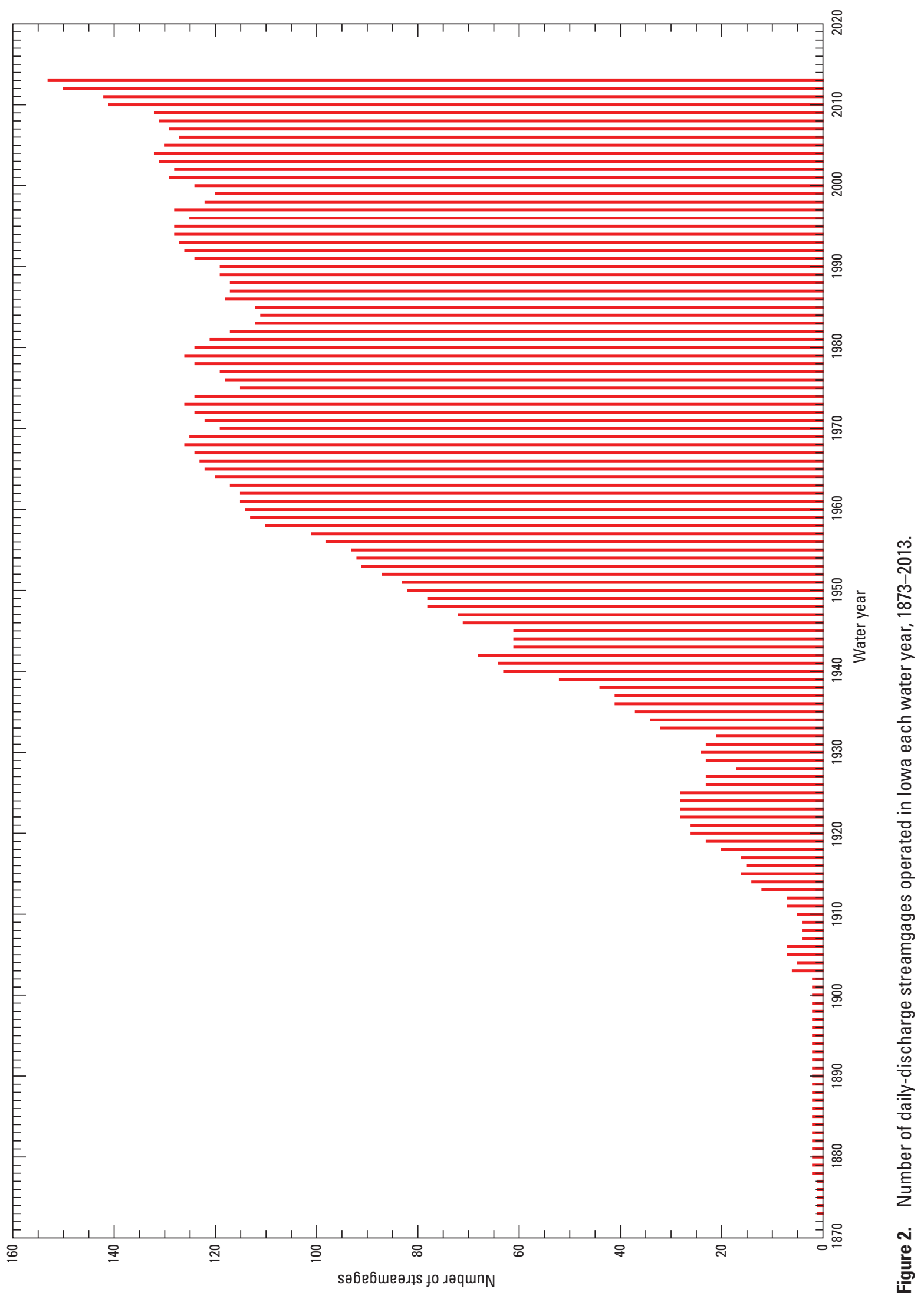




\section{Explanation of Streamgage Summaries and Streamflow Statistics}

Two sets of statistical summaries are presented for each streamgage (refer to link in table 1), which include (1) longterm statistics for the entire period of streamflow record and (2) recent-term statistics for or during the 30-year period of record from 1984 to 2013; however, for the AEPs of instantaneous peak discharges (flood frequencies), statistics are only calculated for the entire period of record. The recent-term statistics are only calculated for streamgages with streamflow records pre-dating the 1984 water year and with at least 10 years of streamflow data available during 1984-2013. The streamgage summaries and statistics consist of nine elements, which are presented in the following order for each streamgage:

- Streamgage description and links to all available data for a streamgage provided through the USGS NWISWeb interface (U.S. Geological Survey, 2015a) and through the USGS WaterWatch Toolkit (U.S. Geological Survey, 2015b).

- Graph of annual mean discharges, mean annual mean discharges, Kentau (Kendall's tau) statistics, $P$-values for the time series of annual mean discharges, 50-percent annual flow-duration discharges (median flows), and harmonic mean flows. Typically, a trend is considered to be significant if the probability $(P)$ value (probability that a true null hypothesis of no trend is erroneously rejected) is less than or equal to 0.05 (Rasmussen and Perry, 2001; Eash and Barnes, 2012; Linhart and others, 2012; Eash and others, 2013), which represents a 95-percent confidence level. Thus, $P$-values less than or equal to 5 percent $(\alpha=0.05)$ indicate statistically significant trends (positive or negative).

- Graph of mean daily mean discharges.

- Graph of flow-duration curves.

- Monthly and annual flow durations, and Kentau statistics and $P$-values for the times series of annual flow durations.

- AEPs of instantaneous peak discharges, and Kentau statistics and $P$-value for the time series of annual peak discharges.

- AEPs of high discharges, and Kentau statistics and $P$-values for the annual time series of selected numbers of consecutive days for high discharges.

- ANPs of low discharges, and Kentau statistics and $P$-values for the annual time series of selected numbers of consecutive days for low discharges.
- ANPs of seasonal low discharges, and Kentau statistics and $P$-values for the annual time series of selected numbers of consecutive days for seasonal low discharges.

The Kendall's tau hypothesis test was used to analyze for trends to determine if there may be any statistically significant trends in the annual times series of streamflow data for mean discharges; flow durations; peak discharges; and selected numbers of consecutive days for high discharges, low discharges, and seasonal low discharges. The Kendall's tau test for annual mean discharges was calculated using the "kensen.test" within the USGS R package smwrStats (Lorenz, 2014c). Kendall's tau tests for annual flow durations were calculated using the USGS Surface Water Statistics (SWSTAT) program within the USGS ANNIE program (Flynn and others, 1995). The Kendall's tau test for annual peak discharges was calculated using the PeakFQ program (Veilleux and others 2014). Kendall's tau tests for the annual time series of selected numbers of consecutive days for high discharges, low discharges, and seasonal low discharges were calculated using the "Trend" preprocessing step of the "Integrated Frequency Analysis" procedure within the USGS surface water (SW) Toolbox program. The Kendall's tau test was used to calculate the monotonic relation between streamflow data (discharges) and time (water years or climatic years) (Helsel and Hirsch, 2002), and is a nonparametric test that can be used to indicate the likelihood of a positive or negative trend with time (Rasmussen and Perry, 2001). Using the Kendall's tau test, the rank of each discharge value in the annual time series is compared to the rank of the values following it in the series. If the second value is consistently greater than the first, the Kentau statistic is positive. If the second value is consistently lower, the Kentau statistic is negative. An equal number of positive and negative values would indicate that a trend does not exist. Thus, the Kentau statistic is a measure of the correlation between the series and time.

Wahl (1998) describes how Kendall's tau test results may be sensitive to multiyear sequences of larger or smaller discharges if the sequences happen near the beginning or end of the period of record used in the test. Although trend results are relatively insensitive to individual outliers, multiyear sequences of extremes near either end of the record can have a significant effect on the test results but may imply no systematic change. Annual time series of streamflow data indicated to have statistically significant trends in this study were not retested to determine if a statistically significant trend may not be indicated with the removal of annual discharges from either the beginning or the end of the record, or from both the beginning and the end of the record (Eash and others, 2013; Eash, 2014).

The streamgage summaries and statistics are presented in downstream order. Streamgages are assigned unique, 8-digit numbers for identification. The first two digits are a part number and refer to major drainage basins. Part 05 refers to the upper Mississippi River Basin and part 06 refers to the Missouri River Basin. The six remaining digits are assigned 
to the streamgage on the basis of downstream order (numbers increase from headwaters to mouth).

Three sets of statistics are presented for streamgages located downstream from flow-regulation dams: the first for the pre-regulated streamflow period, the second for the regulated streamflow period, and the third for the 1984-2013 regulated streamflow period, if at least 10 years of streamflow data are available for the 1984-2013 period. (Refer to the "Effects of Regulation and Water Use" section.)

Annual mean discharges, mean annual mean discharges, annual flow durations, AEPs of instantaneous peak discharges, and AEPs of high discharges were calculated for complete water years of streamflow data. The ANPs of low discharges were calculated for the climatic year. A climatic year is the 12-month period from April 1 through March 31. The climatic year is designated by the calendar year in which the climatic year ends and includes 3 of the 12 months of that year. Thus, the climatic year ending March 31, 2013, is the " 2013 climatic year." The climatic year is used for analyses of ANPs of low discharges because low-flow events in Iowa typically occur during the late summer through winter months. The ANPs of seasonal low discharges were calculated for complete 3-month periods of seasonal record.

More than 5,000 separate statistical analyses were calculated for this study to produce the more than 230,000 unique statistics presented in this report. Most of the statistics in this report were calculated using the USGS SW Toolbox computer program (Kate Flynn, U.S. Geological Survey, written commun., 2014), which implements the USGS SWSTAT program functionality (Lumb and others, 1990) within a modern Windows ${ }^{\mathrm{TM}}$ interface. Unless otherwise noted, all references to the SW Toolbox program are to SWSTAT functionality within SW Toolbox. Specifically, the monthly and annual flow durations were calculated using the "Duration/Compare" procedure within the SW Toolbox program; the AEP of high discharges and the ANP of low discharges and seasonal low discharges were calculated using the "Integrated Frequency Analysis" procedure within the SW Toolbox program. These two SW Toolbox procedures for statistical analyses of time-series data were obtained from the U.S. Environmental Protection Agency (EPA) Better Assessment Science Integrating point and Nonpoint Sources (BASINS) program (U.S. Environmental Protection Agency, 2013). BASINS is a multipurpose environmental analysis system designed to perform watershedand water-quality-based studies. The AEPs of instantaneous peak discharges (flood frequencies) were calculated using the USGS PeakFQ program (version 7.1) (Flynn and others, 2006; Veilleux and others 2014). Annual mean discharges, mean annual mean discharges, 50-percent annual flow-duration discharges (median flows), harmonic mean flows, mean daily mean discharges, and flow-duration curves shown in the three graphs were calculated using three R scripts and four USGS $\mathrm{R}$ packages named DVstats, smwrBase, smwrGraphs, and smwrStats (Lorenz, 2013, 2014a, 2014b, 2014c). The streamflow daily values data used in the SW Toolbox and R-script calculations and the annual instantaneous peak-discharge data used in the PeakFQ calculations were retrieved from the USGS NWISWeb database (U.S. Geological Survey, 2015a).

\section{Streamgage Description}

The streamgage description provides, under various headings, information such as streamgage location, period of record, historical extremes outside the period of record, and other remarks pertinent to streamgage operation and regulation; additional information on streamgage description is provided at http://wdr.water.usgs.gov/current/documentation.html. The USGS Water-Supply Papers (WSPs) were the original medium for publishing streamflow data (for example Wells, 1959). The following information, as appropriate, is provided for each streamgage. Comments follow that clarify information presented under the various headings of the streamgage description.

LOCATION.- Location information is obtained from the most accurate maps available. The location of the streamgage with respect to the cultural and physical features in the vicinity and with respect to the reference place mentioned in the streamgage name is given. In the case of discontinued streamgages, the location is furnished using features present at the time the streamgage was in operation. In many instances, the identifying features have changed since the streamgage was discontinued. Public Land Survey System coordinates (township, range, section) are referenced to the fifth principal meridian unless noted otherwise. River mileages, given for only a few streamgages, were determined by methods given in "River Mileage Measurement," Bulletin 14, revision of October 1968, prepared by the U.S. Water Resources Council (1968) or were provided by the U.S. Army Corps of Engineers (Fischer and Eash, 1998).

DRAINAGE AREA.-Drainage areas are measured using the most accurate maps available. Because the type of maps available varies from one drainage basin to another, the accuracy of drainage areas likewise varies. Drainage areas are updated as more accurate maps become available. Drainage areas of discontinued streamgages were determined at the time the streamgage was in operation.

PERIOD OF RECORD.-This term indicates the time period for which daily mean streamflow data are available for computation of the statistical summaries. For some streamgages, WSPs 1308, 1310, 1728, 1730, and 1914 are shown under this heading and they refer to Water-Supply Papers 1308 (Wells, 1959), 1310 (Wells, 1958), 1728 (Hendricks, 1964a), 1730 (Hendricks, 1964b), and 1914 (U.S. Geological Survey, 1971).

GAGE.-The type of streamgage that was used to collect the streamflow data. The datum of the streamgage is referenced to the National Geodetic Vertical Datum of 1929, except at some streamgages the datum is mean sea level when the records have been furnished to the USGS by other agencies. A 
condensed history of the types, locations, and datums of previous streamgages are also given under this heading.

REMARKS.-Additional information about the streamgage, such as conditions that affect natural streamflow or notes on the accuracy of the records at the site, is provided here.

EXTREMES OUTSIDE PERIOD OF RECORD.--Information here documents major floods or unusually low flows that occurred outside the stated period of record. The information may or may not have been obtained by the USGS.

\section{Graph of Annual Mean Discharges}

The annual mean discharges for the entire period of streamflow record are plotted on a graph. Also shown on the graph are lines depicting the mean of the annual mean discharges, the 50-percent annual flow-duration discharge (median flow), and the harmonic mean flow for the entire streamflow period of record and for the 1984-2013 streamflow period of record, if the streamflow record pre-dates the 1984 water year and at least 10 years of streamflow data are available for the 1984-2013 period. The time series of annual mean discharges are used for the Kendall's tau hypothesis test to analyze for trends. The results of the Kendall's tau tests are listed in the explanation following the mean annual mean discharge value and period of record. The harmonicmean-flow statistic can serve as a design flow for human health criteria that are based on lifetime exposures because it can be used to calculate the average exposure concentration of a contaminant for an average contaminant loading rate (Rossman, 1990; Koltun and Whitehead, 2002); see Eash and Barnes (2012) for more information on the harmonic-meanflow statistic. All statistics are calculated using only complete water years of record. The period of record listed on the graph does not account for water years of missing streamflow data; see the monthly and annual flow-duration table for a listing of complete water years.

\section{Graph of Mean Daily Mean Discharges}

The mean of the daily mean discharges is plotted on a graph for each day of the water year. The mean of the daily mean discharges is calculated using only complete water years of record for the entire streamflow period of record and for the 1984-2013 streamflow period of record, if the streamflow record pre-dates the 1984 water year and at least 10 years of streamflow data are available for the 1984-2013 period. For example, if the entire period of record for a streamgage includes 100 complete water years of record for the period 1914-2013, the mean of the daily mean discharges for October 1 was calculated from 100 daily mean discharge values collected for October 1 during 1914-2013; likewise, the mean of the daily mean discharges is calculated for each other day of the water year. Water years listed on the graph do not account for missing years of streamflow data; see the monthly and annual flow-duration table for a listing of complete water years.

\section{Graph of Flow-Duration Curves}

The flow-duration curves are plotted on a graph for the entire streamflow period of record and for the 1984-2013 streamflow period of record, if the streamflow record pre-dates the 1984 water year and at least 10 years of streamflow data are available for the 1984-2013 period. The flow-duration curve is a cumulative frequency curve that shows the percent of time specified discharges were equaled or exceeded during a given period (Searcy, 1959); the flow-duration curve combines in one curve the flow characteristics of a stream throughout the range of discharge, without regard to the sequence of the occurrence. The flow-duration curves are calculated using only complete water years. Water years listed on the graph do not account for missing years of streamflow data; see the monthly and annual flow-duration table for a listing of complete water years.

\section{Monthly and Annual Flow Durations}

The monthly and annual flow-duration table is a frequency analysis of the daily-discharge values. The daily values are sorted by value and the percentiles calculated. Because the flow durations are calculated on daily values, the percentiles are the same as "percentage of days discharge equaled or exceeded." For example, if the 90-percent flow-duration value for October is 300 cubic feet per second $\left(\mathrm{ft}^{3} / \mathrm{s}\right)$, then 90 percent of the October daily discharge values in the period of record were greater than or equal to $300 \mathrm{ft}^{3} / \mathrm{s}$. The preceding graphs of flow-duration curves are plots of the annual flow-duration values listed in the table. Results of Kendall's tau tests are only presented for the annual flow-duration time series. The results of the Kendall's tau tests are not independent of each other and should be considered in aggregate to evaluate for trends. Flow durations are calculated using only complete water years of record.

\section{Annual Exceedance Probability of Instantaneous Peak Discharges}

The AEP of instantaneous peak discharges, also called flood-frequency discharges, are calculated using procedures recommended by the Interagency Advisory Committee on Water Data (1982). An AEP curve is developed by fitting a Pearson Type-III distribution to the logarithms (base 10) of the annual instantaneous peak discharges collected at a streamgage. In addition to the annual peak discharges measured during the period of systematic record collection (also called the "systematic record"), historic peak-flood information (called the "historical record") often is included in the analyses to effectively extend the length of the flood record. 
The systematic record length is listed as the "Number of peaks" at the bottom of the table and the "historical period length" is listed in the middle of the table. If the AEP curve is historically adjusted, the historic period length is greater than the systematic record length, otherwise it is equal to the systematic record length.

An AEP peak-discharge analysis named the expected moment algorithm (EMA), along with a test for detecting low outliers named the multiple Grubbs-Beck (MGB) test, collectively referred to as the EMA/MGB analysis method (Cohn and others, 1997, 2001, 2013; Eash and others, 2013; Veilleux and others, 2014), was used to calculate the AEP of instantaneous peak discharges for this study. The EMA/MGB analysis method is an optional analysis method within the USGS PeakFQ program (Veilleux and others, 2014). Results of a statewide regional skew study (Veilleux and others, 2012; Eash and others, 2013) were used with the EMA/MGB analysis method to calculate the AEP of instantaneous peak discharges for this study.

The Interagency Advisory Committee on Water Data (1982) recommends that improved estimates of the AEP of peak discharges at streamgages can be obtained by weighting the AEP log-Pearson Type III estimate (EMA/MGB estimate) with a regional regression equation (RRE) estimate using the variance of prediction for each of these two estimates. The variance of prediction can be thought of as a measure of the uncertainty in either the EMA/MGB estimate or the RRE estimate. If the two estimates are assumed to be independent and are weighted inversely proportional to their associated variances, the variance of the weighted estimate will be less than the variance of either of the independent estimates. Optimal weighted estimates of the AEP of instantaneous peak discharges were calculated for this study using the Weighted Independent Estimates (WIE) computer program (Cohn and others, 2012; Eash and others, 2013). The RRE estimates that were used to calculate the WIE estimates for streamgages in this study were obtained from RREs developed for three flood regions defined for Iowa (Eash and others, 2013). The AEP of instantaneous peak discharges tables present WIE estimates and EMA/MGB estimates for a streamgage if the RREs are applicable for calculating WIE estimates (Eash and others, 2013). The WIE estimates are considered to provide better estimates of the AEP of instantaneous peak discharges and are the recommended estimates to use for streamgages, following guidance provided by the USGS Office of Surface Water Technical Memorandum 2010.05 (U.S. Geological Survey, 2010). The EMA/MGB estimates are presented for comparison purposes. Tables of the AEP of instantaneous peak discharges are only presented for the entire streamflow period of record, and not for the 1984-2013 period of record, because of the estimation improvement obtained from historically adjusting the AEP curves for streamgages when historic peak-flood information is available (Interagency Advisory Committee on Water Data, 1982; Cohn and others, 1997; Stedinger and Cohn, 1987; Hosking and Wallis, 1986; Tasker and Thomas, 1978). Also, the AEP of peak discharges becomes more statistically reliable with longer record lengths (Feaster, 2010; Soong and others, 2004). The time series of annual instantaneous peak discharges are used for the Kendall's tau hypothesis test to analyze for trends.

Flood-frequency tabulations list the magnitudes of theoretical instantaneous peak discharges for selected AEPs and corresponding recurrence intervals (RI). An AEP is an estimate of the likelihood of a flood of a specified magnitude happening in any 1 year. For example, a flood magnitude that has a 1-percent chance $(\mathrm{AEP}=0.01)$ of being exceeded during any particular year is expected to be exceeded on average once during any 100-year period (RI=100) (Holmes and Dinicola, 2010). Percent probability is the inverse of the RI multiplied by 100 . Although the annual probability is an estimate of the likelihood of a flood discharge of a specific magnitude happening in any 1 year, more than one flood discharge with a specific magnitude and AEP or RI could happen in the same year.

Flood-frequency tabulations for regulated periods of record for regulated streamgages downstream from Federal dams on the Chariton, Des Moines, Iowa, Mississippi, and Missouri Rivers were obtained from the U.S. Army Corps of Engineers (2003, 2004a, 2004b, 2009, 2010), except for Des Moines River near Runnells (streamgage 05487500, fig. 1, map number 121) and Chariton River near Moulton (streamgage 06904010, fig. 1, map number 184).

\section{Annual Exceedance Probability of High Discharges and Annual Nonexceedance Probability of Low Discharges}

The AEP of high discharges and the ANP of low discharges and seasonal low discharges also are based on fitting the Pearson Type-III distribution to the logarithms of the respective discharges. The USGS has established standard methods for estimating high-flow and low-flow frequency statistics for streamgages (Riggs, 1968, 1972; Lumb and others, 1990; Eash and Barnes, 2012). Unlike flood-frequency analyses, however, no historical data or regional skew data are used. For high-flow discharges, the AEP is the likelihood that the largest discharge will be greater than or equal to the stated magnitude in any 1 year. For annual and seasonal low-flow discharges, the ANP is the likelihood that the smallest discharge will be less than or equal to the stated magnitude in any 1 year.

The AEPs of high discharges are calculated using the maximum mean discharges for any specific number of consecutive days ( $N$-day high flows) during an annual period (water year) for a selected period of record. The ANPs of low discharges are calculated using the minimum mean discharges for any specific number of consecutive days ( $N$-day low flows) during an annual period (climatic year) for a selected period of record. For example, the statistic for the 7-day low-flow value at the 0.10 nonexceedance probability is calculated from the annual series of minimum 7-day mean flows for a streamgage. From the daily mean discharge record, the mean 
flow for each consecutive 7-day period is determined and the lowest mean value for each year is assigned to that year in the annual series. The series of annual minimum 7-day values are then fit to a log-Pearson Type III distribution to develop an ANP curve (Riggs, 1972). Selected ANP discharge values, such as the 7-day low-flow value at the 0.10 nonexceedance probability, are then interpolated from the curve. More specific information about the log-Pearson Type III distribution can be found in Interagency Advisory Committee on Water Data (1982). Low-flow, or high-flow, frequency statistics also can be calculated on a seasonal or monthly basis by limiting the daily mean discharge data used for the annual series to just the season or month of interest. The time series of annual maximum $N$-day values used to calculate AEPs for high discharges and the time series of annual and seasonal minimum $N$-day values used to calculate ANPs for low discharges are the time series used for the Kendall's tau hypothesis test to analyze for trends. The results of these Kendall's tau tests are not independent of each other and should be considered in aggregate to evaluate for trends. Annual and seasonal $N$-day, low-flow discharge values for some streamgages included in this study were equal to zero. A conditional probability adjustment for zero flow values (appendix 5 in Interagency Advisory Committee on Water Data, 1982) was used for low-flow frequency analyses for streamgages with one or more annual or seasonal $\mathrm{N}$-day discharge values of zero.

The AEPs for high discharges and the ANPs for low discharges (especially for low discharges) are prone to inconsistencies. For example, a 3-day low-flow value at the 0.01 nonexceedance probability might be calculated to be less than the 1-day low-flow value calculated for the same nonexceedance probability. When this situation occurred, the frequency curves were modified graphically from the log-Pearson Type-Ill distribution as recommended by the USGS Office of Surface Water Technical Memorandum 89.11 (U.S. Geological Survey, 1989). The AEP values of high discharges, especially for 1- and 3-day high-flow values, occasionally exceeded the AEP values of instantaneous peak discharges when historical records are included in the AEP analyses of peak discharges. When these inconsistencies occurred, the AEP of high discharges for the affected $N$-day analyses were presented as not determined.

The AEPs of high discharges were not calculated for regulated periods of record for regulated streamgages downstream from Federal dams on the Chariton, Des Moines, Iowa, and Missouri Rivers because of the effects of regulation. Users requiring the $\mathrm{AEP}$ of high discharges for these streamgages should contact the U.S. Army Corps of Engineers.

\section{Data Considerations}

\section{Period of Record}

The reliability of statistical streamflow data is related to the length of streamflow record. The Interagency Advisory Committee on Water Data (1982) recommends that at least 10 years of record be used for calculating estimates of the AEP of peak discharges; therefore, the length-of-record criterion for including a streamgage in this report was set at 10 years. Even with this criterion, statistical computations based on short periods of record (for example, 10 to 15 years) still are less reliable than computations based on long periods of record (for example, 50 or more years).

The lengths of streamflow records at streamgages included in this report vary greatly. Extreme high or low flows that are part of the streamflow record of one streamgage might not be part of the record of another streamgage, resulting in apparent inconsistencies in the streamflow statistics when comparing data from two streamgages.

\section{Data Rounding}

The number of significant figures used to report discharges is based on the magnitude of the discharge. Flow duration and probability discharges are rounded according to the criteria listed in table 2 .

Table 2. Significant figures used for reporting flow duration and probability discharges.

\begin{tabular}{lc}
\hline $\begin{array}{c}\text { Range of discharge } \\
\text { (cubic feet per second) }\end{array}$ & Significant figures \\
\hline less than 0.010 & 1 \\
0.10 to 0.99 & 2 \\
1.0 to 9.9 & 2 \\
10 to 99 & 2 \\
greater than or equal to 100 & 3 \\
\hline
\end{tabular}

\section{Effects of Regulation and Water Use}

Streamflows measured at several Iowa streamgages located downstream from Federal dams on the Chariton, Des Moines, Iowa, and Missouri Rivers are affected by reservoir regulation. Reservoir regulation has the effect of decreasing high flows and augmenting low flows downstream from the dam. Because regulation affects streamflow characteristics, three sets of statistics are calculated for streamgages located downstream from reservoirs. The first set is calculated for the period of record before reservoir operation began (pre-regulated streamflow period), the second set is calculated for the period after reservoir operation began (regulated streamflow period), and the third set is calculated for the 1984-2013 regulated streamflow period. Only one set of statistics is calculated 
for the three Mississippi River streamgages, however, because the Mississippi River locks and dams were built for river navigation and have only a minimal regulatory effect on streamflows. For Missouri River streamflow statistics included in this report, significant streamflow regulation is considered to have begun in water year 1953 when storage behind Fort Randall Dam, South Dakota, began in late 1952.

The streamflow statistics in this report are not adjusted for the effects of water use. Total water withdrawals in Iowa are approximately 79 percent from surface water and 21 percent from groundwater (Maupin and others, 2014). The primary uses of surface water in Iowa are thermoelectric power generation, public-water supply, mining, and livestock watering (Maupin and others, 2014). Other surface-water uses include aquaculture, self-supplied industrial, and irrigation. Although some of this water is used consumptively, most of it is returned to the streams.

\section{Summary}

Statistical summaries of streamflow data collected at 184 streamgages in Iowa are presented in this report. All streamgages included for analysis have at least 10 years of continuous record collected before or through September 2013. This report is an update to two previously published reports that presented statistical summaries of selected Iowa streamflow data through September 1988 and September 1996. The statistical summaries include (1) monthly and annual flow durations, (2) annual exceedance probabilities of instantaneous peak discharges (flood frequencies), (3) annual exceedance probabilities of high discharges, and (4) annual nonexceedance probabilities of low discharges and seasonal low discharges. Also presented for each streamgage are graphs of the annual mean discharges, mean annual mean discharges, 50-percent annual flow-duration discharges (median flows), harmonic mean flows, mean daily mean discharges, and flow-duration curves. Two sets of statistical summaries are presented for each streamgage, which include (1) long-term statistics for the entire period of streamflow record and (2) recent-term statistics for or during the 30-year period of record from 1984 to 2013. The recent-term statistics are only calculated for streamgages with streamflow records pre-dating the 1984 water year and with at least 10 years of record during 1984-2013. The streamflow statistics in this report are not adjusted for the effects of water use; although some of this water is used consumptively, most of it is returned to the streams.

\section{References Cited}

Burmeister, I.L., 1970, The streamflow data program in Iowa, evaluation of the past, proposal for the future: U.S. Geological Survey Open-File Report 70-48, 85 p.

Cohn, T.A., Berenbrock, Charles, Kiang, J.E., and Mason, R.R., Jr., 2012, Calculating weighted estimates of peak streamflow statistics: U.S. Geological Survey Fact Sheet 2012-2038, 4 p., accessed April 17, 2015, at http://pubs. usgs.gov/fs/2012/3038/ and http://water.usgs.gov/usgs/osw/ swstats/freq.html.

Cohn, T.A., England, J.F., Berenbrock, C.E., Mason, R.R., Stedinger, J.R., and Lamontagne, J.R., 2013, A generalized Grubbs-Beck test statistic for detecting multiple potentially influential low outliers in a flood series: Water Resources Research, v. 49, no. 8, p. 5047-5058, accessed March 9, 2015, at http://onlinelibrary.wiley.com/doi/10.1002/ wrer.20392/pdf.

Cohn, T.A., Lane, W.L., and Baier, W.G., 1997, An algorithm for computing moments-based flood quantile estimates when historical flood information is available: Water Resources Research, v. 33, no. 9, p. 2089-2096, accessed April 23, 2015, at http://onlinelibrary.wiley.com/ doi/10.1029/97WR01640/pdf.

Cohn, T.A., Lane, W.L., and Stedinger, J.R., 2001, Confidence intervals for expected moments algorithm flood quantile estimates: Water Resources Research, v. 37, no. 6, p. 1695-1706, accessed April 23, 2015, at http://timcohn.com/ Publications/CohnLaneSted2001WR900016.pdf.

Dixon, Harry, Lawler, D.M., Shamseldin, A.Y., and Webster, Paul, 2006, The effect of record length on the analysis of river flow trends in Wales and Central England, in Proceedings of the Fifth FRIEND World Conference, Climate Variability and Change-Hydrologic Impacts, November 2006: Havana, Cuba, International Association of Hydrological Sciences, publication 308, p. 490-495, accessed June 29, 2015, at http://www.researchgate.net/ publication/245791414_The_effect_of_record_length_on_ the_analysis_of_river_flow_trends_in_Wales_and_Central_ England.

Eash, D.A., 2014, Summary of U.S. Geological Survey reports documenting flood profiles of streams in Iowa, 1963-2012: U.S. Geological Survey Scientific Investigations Report 2014-5085, 32 p., accessed June 24, 2015, at http://dx.doi.org/10.3133/sir20145085.

Eash, D.A., and Barnes, K.K., 2012, Methods for estimating selected low-flow frequency statistics and harmonic mean flows for streams in Iowa: U.S. Geological Survey Scientific Investigations Report 2012-5171, 99 p., accessed April 16, 2015, at http://pubs.usgs.gov/sir/2012/5171/sir2012-5171. pdf. 
Eash, D.A., Barnes, K.K., and Veilleux, A.G., 2013, Methods for estimating annual exceedance-probability discharges for streams in Iowa, based on data through water year 2010: U.S. Geological Survey Scientific Investigations Report 2013-5086, 63 p. with appendix, accessed April 17, 2015, at http://pubs.usgs.gov/sir/2013/5086/.

Feaster, T.D., 2010, Importance of record length with respect to estimating the 1-percent chance flood, in Proceedings of the 2010 South Carolina Water Resources Conference, October 13-14, 2010: Columbia, South Carolina, 4 p., accessed April 23, 2015, at http://media.clemson. edu/public/restoration/scwrc/2010/manuscripts/t1/ feastert_10scwrcpaper.pdf.

Fischer, E.E., 1996, Survey of users of the USGS streamgaging network in Iowa, 1996: U.S. Geological Survey Open-File Report 96-185, 35 p., accessed April 22, 2015, at http://pubs.usgs.gov/of/1996/0185/report.pdf.

Fischer, E.E., and Eash, D.A., 1998, Statistical summaries of selected Iowa streamflow data through September 1996: U.S. Geological Survey Open-File Report 98-170, 681 p., accessed April 7, 2015, at http://pubs.usgs.gov/ of/1998/0170/report.pdf.

Fischer, E.E., Melcher, N.B., and Kluesner, S.P., 1990, Statistical summaries of selected Iowa streamflow data through September 30, 1988: U.S. Geological Survey Open-File Report 90-170, 641 p., accessed April 7, 2015, at http:// pubs.usgs.gov/of/1990/0170/report.pdf.

Flynn, K.M., Hummel, P.R., Lumb, A.M., and Kittle, J.L., Jr., 1995, User's manual for ANNIE, version 2, a computer program for interactive hydrologic data management: U.S. Geological Survey Water-Resources Investigations Report 95-4085, 211 p., accessed April 17, 2015, at http:// water.usgs.gov/software/ANNIE/code/doc/annie.pdf.

Flynn, K.M., Kirby, W.H., and Hummel, P.R., 2006, User's manual for program PeakFQ, annual flood-frequency analysis using Bulletin 17B guidelines: U.S. Geological Survey Techniques and Methods, book 4, chap. B4, 42 p., accessed April 16, 2015, at http://pubs.usgs.gov/tm/2006/tm4b4/ tm4b4.pdf and http://water.usgs.gov/software/PeakFQ/.

Helsel, D.R., and Hirsch, R.M., 2002, Statistical methods in water resources: U.S. Geological Survey Techniques of Water-Resources Investigations, book 4, chap. A3, 510 p., accessed April 17, 2015, at http://pubs.usgs.gov/twri/ twri4a3/\#pdf.

Hendricks, E.L., 1964a, Compilation of records of surface waters of the United States, October 1950 to September 1960. Part 5, Hudson Bay and Upper Mississippi River Basins: U.S. Geological Survey Water-Supply Paper 1728, 576 p., accessed November 16, 2015, at http://pubs.usgs. gov/wsp/1728/report.pdf.
Hendricks, E.L., 1958b, Compilation of records of surface waters of the United States, October 1950 to September 1960. Part 6-B, Missouri River Basin below Sioux City, Iowa: U.S. Geological Survey Water-Supply Paper 1730, 619 p., accessed November 16, 2015, at http://pubs.usgs. gov/wsp/1730/report.pdf.

Holmes, R.R., Jr., and Dinicola, K., 2010, 100-year flood-It's all about chance: U.S. Geological Survey General Information Product 106, 1 p., accessed April 21, 2015, at http:// pubs.usgs.gov/gip/106/pdf/100-year-flood-handout-042610. pdf.

Hosking, J.R.M., and Wallis, J.R., 1986, The value of historical data in flood frequency analysis: Water Resources Research, v. 22, no. 11, p. 1606-1612, accessed April 23, 2015, at http://onlinelibrary.wiley.com/doi/10.1029/ WR022i011p01606/pdf.

Interagency Advisory Committee on Water Data, 1982, Guidelines for determining flood flow frequency: U.S. Geological Survey, Office of Water Data Coordination, Bulletin 17B of the Hydrology Subcommittee, 28 p., plus appendixes, accessed April 17, 2015, at http://water.usgs.gov/osw/ bulletin17b/bulletin_17B.html.

Jian, Xiaodong, Wolock, D.M., Lins, H.F., and Brady, Steve, 2014, Streamflow of 2013-Water year summary: U.S. Geological Survey Fact Sheet 2014-3030, 8 p., accessed April 7, 2015, at http://dx.doi.org/10.3133/ fs20143030.

Koltun, G.F., and Whitehead, M.T., 2002, Techniques for estimating selected streamflow characteristics of rural, unregulated streams in Ohio: U.S. Geological Survey Water-Resources Investigations Report 02-4068, 50 p., accessed April 16, 2015, at http://oh.water.usgs.gov/reports/ wrir/wrir02-4068.pdf.

Linhart, S.M., Nania, J.F., Sanders, C.L., Jr., and Archfield, S.A., 2012, Computing daily mean streamflow at ungaged locations in Iowa by using the Flow Anywhere and Flow Duration Curve Transfer statistical methods: U.S. Geological Survey Scientific Investigations Report 2012-5232, 50 p., accessed April 17, 2015, at http://pubs.usgs.gov/ sir/2012/5232/.

Lorenz, D.L., 2013, DVstats, functions to manipulate dailyvalues data: U.S. Geological Survey, accessed April 21, 2015, at https://github.com/USGS-R/DVstats.

Lorenz, D.L., 2014a, Functions to import and manipulate hydrologic data: U.S. Geological Survey, accessed April 21, 2015, at https://github.com/USGS-R/smwrBase.

Lorenz, D.L., 2014b, Graphing functions: U.S. Geological Survey, accessed April 21, 2015, at https://github.com/ USGS-R/smwrGraphs. 
Lorenz, D.L., 2014c, General tools for hydrologic data and trend analysis: U.S. Geological Survey, accessed April 21, 2015, at https://github.com/USGS-R/smwrStats.

Lumb, A.M., Kittle, J.L., Jr., and Flynn, K.M., 1990, Users manual for ANNIE, a computer program for interactive hydrologic analyses and data management: U.S. Geological Survey Water-Resources Investigations Report 89-4080, 236 p., accessed April 16, 2015, at http://water.usgs.gov/ software/SWSTAT/.

Maupin, M.A., Kenny, J.F., Hutson, S.S., Lovelace, J.K., Barber, N.L., and Linsey, K.S., 2014, Estimated use of water in the United States in 2010: U.S. Geological Survey Circular 1405, 56 p., accessed April 21, 2015, at http://dx.doi. org/10.3133/cir1405.

Natural Resources Conservation Service, 2015, 30-year climatic and hydrologic normal (1981-2010): Natural Resources Conservation Service, accessed June 29, 2015 , at http://www.wcc.nrcs.usda.gov/normals/30year_normals data.htm.

Rantz, S.E., and others, 1982, Measurement and computation of streamflow-Volume 1, Measurement of stage and discharge; Volume 2, Computation of discharge: U.S. Geological Survey Water-Supply Paper 2175, 631 p., accessed September 16, 2015, at http://pubs.usgs.gov/wsp/wsp2175/.

Rasmussen, T.J., and Perry, C.A., 2001, Trends in peak flows of selected streams in Kansas: U.S. Geological Survey Water-Resources Investigations Report 01-4203, 62 p., accessed April 17, 2015, at http://ks.water.usgs.gov/pubs/ reports/wrir.01-4203.html.

Riggs, H.C., 1968, Frequency curves: U.S. Geological Survey Techniques of Water-Resources Investigations, book 4, chap. A2, 15 p., accessed April 21, 2015, at http://pubs.usgs. gov/twri/twri4a2/.

Riggs, H.C., 1972, Low-flow investigations: U.S. Geological Survey Techniques of Water-Resources Investigations, book 4, chap. B1, 18 p., accessed April 21, 2015, at http:// pubs.usgs.gov/twri/twri4b1/index.html.

Rossman, L.A., 1990, DFLOW user's manual: Cincinnati, Ohio, U.S. Environmental Protection Agency, Risk Reduction Engineering Laboratory, 26 p., accessed April 16, 2015 , at http://nepis.epa.gov/Adobe/PDF/30001JEH.PDF.

Searcy, J.M., 1959, Flow-duration curves, manual of hydrology_Part 2, low-flow techniques: U.S. Geological Survey Water-Supply Paper 1542-A, 33 p., accessed April 16, 2015, at http://pubs.usgs.gov/wsp/1542a/report.pdf.
Soong, D.T., Ishii, A.L., Sharpe, J.B., and Avery, C.F., 2004, Estimating flood-peak discharge magnitudes and frequencies for rural streams in Illinois: U.S. Geological Survey Scientific Investigations Report 2004-5103, 158 p. with appendixes, accessed December 17, 2015, at http://pubs. er.usgs.gov/publication/sir20045103.

Stedinger, J.R., and Cohn, T.A., 1987, Historical flood-frequency data, Its value and use, in Singh, V.P., ed., Regional flood frequency analysis: Norwell, Mass., D. Reidel, p. 273-286.

Tasker, G.D., and Thomas, W.O., 1978, Flood frequency analysis with pre-record information: Journal of Hydraulic Engineering, American Society of Civil Engineers, v. 104, no. 2, p. 249-259.

U.S. Army Corps of Engineers, 2003, Upper Mississippi River system flow frequency study, Hydrology and hydraulics, Appendix F, Missouri River, Omaha District: U.S. Army Corps of Engineers, 488 p., accessed April 21, 2015, at http://www.mvr.usace.army.mil/Portals/48/docs/FRM/ UpperMissFlowFreq/App.\%20F\%20Omaha\%20Dist. $\% 20$ Hydrology_Hydraulics\%20Report.pdf.

U.S. Army Corps of Engineers, 2004a, Upper Mississippi River system flow frequency study, Hydrology and hydraulics, Appendix B, St. Paul District: U.S. Army Corps of Engineers, 71 p., accessed April 21, 2015, at http://www.mvr.usace.army.mil/Portals/48/docs/FRM/ UpperMissFlowFreq/App.\%20B\%20St.\%20Paul\%20 Dist.\%20Hydrology_Hydraulics.pdf.

U.S. Army Corps of Engineers, 2004b, Upper Mississippi River system flow frequency study, Hydrology and hydraulics, Appendix C, Mississippi River, Rock Island District: U.S. Army Corps of Engineers, 50 p., accessed April 21, 2015, at http://www.mvr.usace.army.mil/Portals/48/docs/ FRM/UpperMissFlowFreq/App.\%20C\%20Rock\%20 Island\%20Dist.\%20Mississippi\%20River\%20Hydrology_ Hydraulics.pdf.

U.S. Army Corps of Engineers, 2009, Iowa River regulated flow frequency study, Final report: Rock Island District, $65 \mathrm{p}$.

U.S. Army Corps of Engineers, 2010, Des Moines River regulated flow frequency study: Rock Island District, 82 p., accessed April 21, 2015, at http://www.mvr.usace.army.mil/ Portals/48/docs/FRM/DMRRFFS/DMRRFFS-FinalReport. pdf.

U.S. Department of Commerce, National Oceanic and Atmospheric Administration, and National Climatic Data Center, 2013, National Geodetic Survey: accessed April 22, 2015, at http://www.ngs.noaa.gov/TOOLS/Vertcon/vertcon.html. 
U.S. Department of Commerce, National Oceanic and Atmospheric Administration, 2015, Climate normal: National Oceanic and Atmospheric Administration, accessed June 29, 2015 at https://www.ncdc.noaa.gov/data-access/land-basedstation-data/land-based-datasets/climate-normals.

U.S. Environmental Protection Agency, 2013, BASINS 4.1: U.S. Environmental Protection Agency, accessed April 16, 2015, at http://water.epa.gov/scitech/datait/models/basins/ index.cfm.

U.S. Geological Survey, 1971, Surface water supply of the United States, 1961-65, Part 5, Hudson Bay and Upper Mississippi River Basins, v. 2, Upper Mississippi River Basin above Keokuk, Iowa: U.S. Geological Survey Water Supply Paper 1914, 750 p. accessed November 16, 2015, at http:// pubs.usgs.gov/wsp/1914/report.pdf.

U.S. Geological Survey, 1989, Recommendations for regional low-flow studies: U.S. Geological Survey Office of Surface Water Technical Memorandum 89.11, accessed October 13, 2015 at http://water.usgs.gov/admin/memo/SW/sw89.11. html.

U.S. Geological Survey, 2005, Streamflow trends in the United States: U.S. Geological Survey Fact Sheet 2005-3017, 3 p., accessed June 29, 2015, at http://pubs.usgs.gov/ fs/2005/3017/.

U.S. Geological Survey, 2010, Weighted estimates of peak flow frequency statistics: U.S. Geological Survey Office of Surface Water Technical Memorandum 2010.05, 3 p., accessed October 13, 2015, at http:/water.usgs.gov/admin/ $\mathrm{memo} / \mathrm{SW} / \mathrm{sw} 10.05 . \mathrm{pdf}$.

U.S. Geological Survey, 2015a, National Water Information System (NWISWeb): U.S. Geological Survey database, accessed April 16, 2015, at http:/waterdata.usgs.gov/nwis/ Sw.

U.S. Geological Survey, 2015b, WaterWatch: U.S. Geological Survey Web site, accessed April 22, 2015, at http:// waterwatch.usgs.gov/.

Publishing support provided by: Rolla Publishing Service Center

For more information concerning this publication, contact: Director, USGS lowa Water Science Center P.O. Box 1230 lowa City, IA 52244 (319) 337-4191

Or visit the lowa Water Science Center Web site at: http://ia.water.usgs.gov/
U.S. Water Resources Council, 1968, River mileage measurement: Hydrology Committee, Bulletin 14, revised October 1968, 17 p.

Veilleux, A.G., Cohn, T.A., Flynn, K.M., Mason, R.R., Jr., and Hummel, P.R., 2014, Estimating magnitude and frequency of floods using the PeakFQ 7.0 program: U.S. Geological Survey Fact Sheet 2013-3108, 2 p., accessed April 16, 2015, at http://dx.doi.org/10.3133/fs20133108 and http:// water.usgs.gov/software/PeakFQ/.

Veilleux, A.G., Stedinger, J.R., and Eash, D.A., 2012, Bayesian WLS/GLS regression for regional skewness analysis for crest stage gage networks, in Loucks, E.D., ed., Proceedings of the World Environmental and Water Resources Congress - Crossing boundaries, May 20-24, 2012 [abs.]: Albuquerque, N. Mex., American Society of Civil Engineering, paper 227, p. 2253-2263, accessed April 17, 2015, at http:// ia.water.usgs.gov/media/pdf/report/Veilleux-StedingerEash-EWRI-2012-227R.pdf.

Wahl, K.L., 1998, Sensitivity of non-parametric trend analyses to multi-year extremes, in Proceedings of the Western Snow Conference, April 20-23, 1998: Snowbird, Utah, Western Snow Conference, p. 157-160, accessed June 24, 2015, at http://westernsnowconference.org/sites/ westernsnowconference.org/PDFs/1998Wahl.pdf.

Wahl, K.L., and Crippen, J.R., 1984, A pragmatic approach to evaluating a multipurpose stream-gaging network: U.S. Geological Survey Water-Resources Investigations Report 84-4228, 13 p., accessed April 22, 2015, at http:// pubs.usgs.gov/wri/1984/4228/report.pdf.

Wells, J.V.B., 1958, Compilation of records of surface waters of the United States through September 1950. Part 6-B, Missouri River Basin below Sioux City, Iowa: U.S. Geological Survey Water-Supply Paper 1310, 619 p., accessed November 16, 2015, at http://pubs.usgs.gov/wsp/1310/ report.pdf.

Wells, J.V.B., 1959, Compilation of records of surface waters of the United States through September 1950. Part 5, Hudson Bay and Upper Mississippi River Basins: U.S. Geological Survey Water-Supply Paper 1308, 708 p., accessed November 16, 2015, at http://pubs.usgs.gov/wsp/1308/ report.pdf.

World Meteorological Organization, 2015, Climate data and data related products: World Meteorological Organization, accessed June 29, 2015, at http://www.wmo.int/pages/ themes/climate/climate_data_and_products.php. 



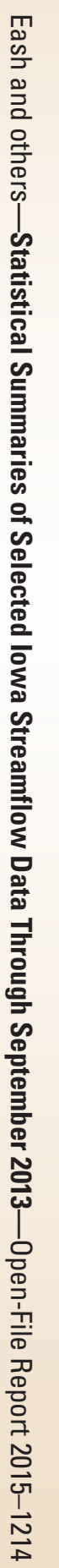

